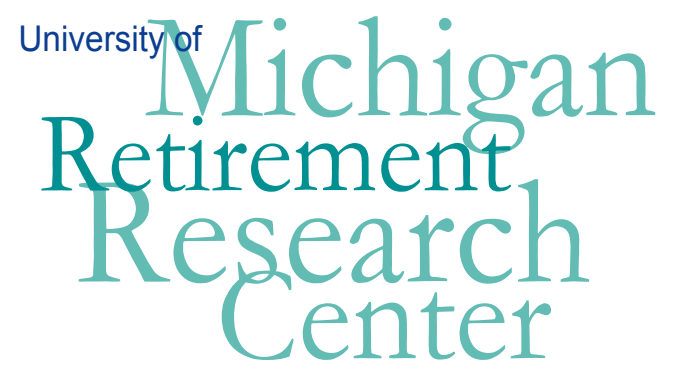

Working Paper

WP 2002-025

\title{
Transition Paths and Social Security Reform John Laitner
}

\begin{tabular}{|l|l|}
\hline $\mathrm{M}$ & $\mathrm{R}$ \\
\hline $\mathrm{R}$ & $\mathrm{C}$ \\
\hline
\end{tabular}$\quad$ Project \#: UM01-05 


\title{
"Transition Paths and Social Security Reform" \\ John Laitner \\ University of Michigan
}

\author{
June 2002 \\ Michigan Retirement Research Center \\ University of Michigan \\ P.O. Box 1248 \\ Ann Arbor, MI 48104 \\ www.mrrc.isr.umich.edu \\ (734) 615-0422
}

\section{Acknowledgements}

This work was supported by a grant from the Social Security Administration through the Michigan Retirement Research Center (Grant \# 10-P-98358-5). The opinions and conclusions are solely those of the authors and should not be considered as representing the opinions or policy of the Social Security Administration or any agency of the Federal Government.

\section{Regents of the University of Michigan}

David A. Brandon, Ann Arbor; Laurence B. Deitch, Bingham Farms; Daniel D. Horning, Grand Haven; Olivia P. Maynard, Goodrich; Rebecca McGowan, Ann Arbor; Andrea Fischer Newman, Ann Arbor; S. Martin Taylor, Gross Pointe Farms; Katherine E. White, Ann Arbor; Mary Sue Coleman, ex officio 


\section{Transition Paths and Social Security Reform}

According to the Economic Report of the President 1999, in 1929 there were $9.6 \%$ as many people over age 65 in the U.S. as between the ages of 20-64; in 1969 the percentage was 18.6; in 1998 it was 21.6. The rise reflects, of course, increasing longevity and declining birth rates. Evidently the U.S. economy is in the midst of period in which the consumption of the elderly will rise as a fraction of total output. Assuming past trends continue, questions arise as to how our society can make required resource reallocations without straining intergenerational amity or eroding the work and saving incentives of the young. The social security system provides a principal source of support for many elderly households. Thinking about social security, moving in the direction of a funded system, perhaps utilizing private accounts, is one possible avenue of reform. Funding the system might help to clarify for participants the relation between their taxes and benefits, and it might facilitate further reform which expands the latitude for individual choice. This paper examines funding changes from a macroeconomic perspective, paying particular attention to the possible transition process from an unfunded social security system to a funded one, and to interactions of social security and aggregate private wealth accumulation.

Section 1 formalizes the connection between national debt and unfunded social security liabilities: within the context of the type of model economists often employ for macroeconomic analysis of public policy, Section 1 outlines a procedure for shifting from an unfunded to a funded social security system - using changes in the national debt - in a way which leaves physical investment and interest rates and wage rates unaffected. The economy's total liabilities, explicit and implicit, would remain the same, but the balance would shift to the "explicit" side. In principle, society could engineer such a shift rapidly.

Section 2 considers possible benefits of shifting to a funded system, or at least of conceptualizing the economic implications of the present system in terms of those it would have if it were funded.

Section 3 briefly considers possible advantages and disadvantages of proceeding to a second stage of reform aimed at reducing the national debt. Analysts often combine the two stages. ${ }^{1}$ In contrast, this paper proposes thinking about elements of reform separately. One potential benefit of the latter strategy is that a society conceivably would favor Section 1's first stage of reform but not Section 4's second.

Section 4 considers implementation of a second stage of reform, reducing the national debt. Outcomes are seen to depend heavily upon one's framework of analysis.

\section{Transition to a Funded Social Security System}

Economists frequently rely on nonstochastic, dynamic general equilibrium models to study potential policy changes (i.e., Auerbach and Kotlikoff [1987], Laitner [1990], Kotlikoff [1998], Feldstein and Samwick [1997, 1998]). This section argues that in such a

${ }^{1}$ In fact, recent studies often investigate reform plans which simultaneously (i) address imminent social security tax shortfalls due to demographic change, (ii) generate new revenues to lower the system's long-run implicit debt, and (iii) move, at least partially, to a funded system (e.g., Kotlikoff [1998], Feldstein and Samwick [1997, 1998], Shoven [1999], President's Commission [2001]). 
context, it is possible to think of a transition from an unfunded to a funded social security system that is neither complicated nor time consuming.

Let us work with an illustrative example in which we start with an unfunded social security system in which taxes and benefits exactly balance. ${ }^{2}$

Suppose the economy has households of two types, young and old. For simplicity, let the two groups always be the same size as one another, there being no overall population growth. The young work, earning, say, $E_{t}$ dollars at date $t$ (per young household). Over time, assume technological progress, at rate $g$, lifts earnings so that

$$
E_{t+1}=E_{t} \cdot(1+g), \quad g>0 .
$$

The old are retired. Households young one year will be old the next. Young households pay part of their earnings, $T_{t}$ per young household at time $t$, in social security taxes; at time $t$, each old household receives $B_{t}$ dollars in social security benefits. Initially, the social security system is unfunded, taxes on the young immediately flowing to benefits to contemporaneous retirees. Thus,

$$
B_{t}=T_{t} \quad \text { all } \quad t .
$$

For simplicity, suppose we begin with no government debt. ${ }^{3}$ Suppose that social security taxes and benefits rise with living standards through time as in (1):

$$
B_{t+1}=B_{t} \cdot(1+g) \quad \text { and } \quad T_{t+1}=T_{t} \cdot(1+g) \quad \text { all } \quad t .
$$

Let the real interest rate be $r$.

Now consider a way in which the economy could fund the social security system. Throughout the remaining discussion assume that the market interest rate $r$ exceeds the economy's natural growth rate $g .{ }^{4}$

Stage-1 Reform: At time 0, collect social security tax $T_{0}$ from each young household and pay benefit $B_{0}$ to each old household; and, issue new government bonds in amount $B_{1} /(1+r)$ to each young household, mandating that the household deposit them in a private account. At every $t>0$, in place of social security taxes, mandate that each young household deposit $B_{t+1} /(1+r)$, i.e., the present value of its former social security benefits, into a private account, invested in government bonds; and, levy a new tax, call it the "debt service tax," of $T_{t}-B_{t+1} /(1+r)$ on each young household. For every $t>0$, in place of former social security benefits, each old household can cash in its private account, yielding $B_{t}$ dollars to finance its retirement. At time 0, the government creates new national debt equaling $B_{1} /(1+r)$ per young household. At subsequent dates, the government rolls the new debt, including accumulations, over, allowing that debt's principal to grow at rate $g$.

${ }^{2}$ In a different context, Geanakoplos et al. [1999] present a similar argument. See also Appendix 1 below.

3 If there is an existing government debt, income taxes on the young and old pay the debt service.

4 This is a common assumption, see Abel et al. [1989]. In fact, it is not essential in this section. 
Consider the impact on households.

At time 0 , government collects social security tax $T_{0}$ from each young household, transferring the same amount to each old household. Reform, therefore, does not affect households which are old at time 0 .

At time 0 , the government prints new bonds and gives each young household bonds having the same present value as that household's social security benefit prior to reform, i.e., $B_{1} /(1+r)$. We can think of the government as setting up a "private account" containing the new bonds for each young household. ${ }^{5}$ The accounts replace, dollar for dollar, every young household's previously expected social security benefits. A young household's lifetime resources, in present value at time 0 , formerly were

$$
E_{0}-T_{0}+\frac{B_{1}}{1+r},
$$

the first term being its earnings, the second its social security tax, and the third its social security benefit. After reform, the same household's lifetime resources are

$$
E_{0}-T_{0}+\frac{B_{1}}{1+r},
$$

where the first term is its earnings, the second is its social security tax, and the third is its time -0 government transfer, the latter creating the household's new private account. Although the young household's social security benefit is gone, its lifetime resources are the same as before.

At time 1, social security taxes and benefits are gone. Old households cash in the government bonds from their private accounts, receiving $B_{1}$ each. Government mandates that each young household establish a private account, with the household purchasing $B_{2} /(1+r)$ dollars worth of government bonds. The government also collects a new tax, call it the "debt service tax," equaling the difference between the household's former social security tax, which no longer exists, and the private-account purchase. The amount of the new tax per young household, therefore, is

$$
T_{1}-\frac{B_{2}}{1+r} .
$$

Formerly a young household's lifetime resources, in present value, were

$$
E_{1}-T_{1}+\frac{B_{2}}{1+r},
$$

with the first term its earnings, the second its social security tax, and the third its social security benefit. Now, its lifetime resources are

$$
E_{1}-\left(T_{1}-\frac{B_{2}}{1+r}\right),
$$

${ }^{5}$ These bonds are analogous to the "recognition bonds" in Feldstein [1998]. Note that Feldstein's approach differs from ours: after issuing recognition bonds in period 0 , he holds the new debt constant, which requires requires new tax revenues - see Section 3 below. 
where it still has the same earnings, but the second term represents its new debt service tax. Comparing (5) and $\left(5^{\prime}\right)$, we can see the lifetime resources of a household in this birth cohort are unchanged.

At time 2, old household's cash the bonds in their private accounts, withdrawing $B_{2}$, exactly the amount their former social security benefits. Young households make a mandatory private account deposit of $B_{3} /(1+r)$ and pay a debt service tax of $T_{2}-B_{3} /(1+$ $r)$. Formerly, the present value of such a household's lifetime resources was

$$
E_{2}-T_{2}+\frac{B_{3}}{1+r},
$$

with $E_{2}$ earnings, $T_{2}$ the social security tax, and $B_{3} /(1+r)$ the present value of social security benefits. Under reform, the household's mandatory deposit in its private account is not a tax since it is counterbalanced by the value of ownership rights to the account; so, a young household's lifetime resources are

$$
E_{2}-\left(T_{2}-\frac{B_{3}}{1+r}\right),
$$

where the first term is earnings, and the second is the new debt service tax. Again, (6) and $\left(6^{\prime}\right)$ are the same.

The pattern continues in subsequent years. The suggested reform leaves every household's lifetime resources unchanged. Tables 1-2 review the descriptions above.

Consider the impact on the government's budget.

Tables $3-3^{\prime}$ show the government's budget constraint. Table 3 reflects the balance of (2) under the old system. With reform, government makes a one-time transfer at time 0 to set up private accounts, financing the transfer with new debt. Subsequently, new debt grows at rate $g$ - see Table 5. The proportionate rise is a source of revenue to the government. The debt-service tax on households, reflecting the residual from the old social security tax less the new mandatory private account contribution, is also a new source of government revenue. The two sources together are exactly sufficient to meet the interest obligations on the new government bonds in the private accounts in all years see Table $3^{\prime}$.

What happens to the economy's overall saving rate and to investment?

The appearance and growth of the new national debt constitute deficit finance and therefore enter the national income and product accounts as negative government saving - see Table 4. On the other hand, the new system of private accounts generates fresh household saving. At time 0, government transfers finance new accounts of $B_{1} /(1+r)$ for each young household, so that private saving grows by that amount. At time 1 , the new private accounts of young households increase private saving by $B_{2} /(1+r)$ per young household; however, as old households liquidate their private accounts to finance their retirement, they dissave $B_{1} /(1+r)$ per household. The process continues in subsequent years - see Table 4. As the table shows, in each year new government deficits exactly offset the increase in household saving due to funded private accounts. Hence, reform does not affect aggregate national income and product account saving. In a closed economy, 
saving equals investment; so, physical investment remains the same. ${ }^{6}$ In turn, interest and wage rates need not change (as our discussion above implicitly assumes).

Thus, we have outlined a way of funding the social security system in a single period. Doing so enlarges the national debt. Prior to reform, on the other hand, promised future social security benefits to living households constitute implicit liabilities. A comparison of the top and bottom of Table 5 shows the government's total balance sheet is, in economic terms, unaffected by our reform: explicit debt merely replaces implicit liabilities, the shift being dollar for dollar. The total balance reflects the history of the current system (a topic to which Section 2 returns).

Although the illustrative example is highly stylized, the logic of the equivalence result is much more general. It can accommodate, for instance, multiperiod life spans. With an individual having $N$ periods of life, at time 0 government would transfer bonds equaling, in present value, the individual's vested social security benefits to date. Subsequently, the individual would make his own additional contributions, and pay debt service tax.

Appendix 1 shows changes in the interest rate over time complicate but do not invalidate the analysis. The appendix uses the well-know Diamond [1965] overlapping generations model and does not assume a steady state.

Appendix 2 shows that it is not even essential to our argument that government pay the market rate of interest on bonds funding private accounts - provided the accounts are heavily regulated and mandatory. A high rate would imply the initial transfer of bonds could be small, though the subsequent interest payments would be great; a low rate would imply the initial transfer must be large, though future interest payments could be less. ${ }^{7}$ There is a longstanding puzzle in economics of why the average rate of return on, say, government bonds is so much lower than the average return on common stock. ${ }^{8}$ Although the answer surely rests on risk and risk aversion, which are outside the scope of this paper, even a nonstochastic model must specify whether "the interest rate" it uses corresponds to the empirical return on bonds or stocks. Appendix 2 suggests that this need not be a stumbling block in our analysis. Presumably, government would, nevertheless, choose an interest rate close to market levels for bonds - say, the rate for inflation-protected government bonds.

Nor would an elastic labor supply affect our logic. Suppose the social security tax is a proportional tax on earnings. Prior to stage -1 reform, a generation- $t$ young household pays $T_{t}$, and anticipates receiving benefits of present value $B_{t+1} /(1+r)$. Conceptually, the household pays $B_{t+1} /(1+r)$ with the prospect of receiving market rate of return $r$, and it pays $T_{t}-B_{t+1} /(1+r)$ with the prospect of not receiving anything back at all. After reform, the same household deposits $B_{t+1} /(1+r)$ in its private account, with the prospect of realizing rate of return $r$, and it pays debt service tax $T_{t}-B_{t+1} /(1+r)$, with the prospect of not receiving anything back at all. In other words, the household's work incentives do not change.

6 In terms of levels, the new private accounts raise net worth, but the increase in private net worth is just sufficient to finance the new government debt - there is no extra new portfolio space for incremental physical capital.

7 Feldstein and Samwick [1997,tab. 8] provides an example related to this point.

8 E.g., Kocherlakota [1996]. 
This section concludes with three comments.

First, the analysis so far has several theoretical implications. (i) Instead of having separate literatures on debt reduction and changes in social security, the arguments above suggest that one can transform many social security problems into analyses of national debt. (ii) This section's hypothetical reform specifies a procedure for constructing an index of the "burden" to an economy of an unfunded social security system - the "burden" being the size of the national debt which one creates in the process of instantaneously funding the system.

Second, quantitatively, the size of the implicit debt from the U.S. social security system is very substantial. Geanakoplos et al [1999, tab. 6], for example, use a 1997 figure of $\$ 8.9$ tril. The explicit Federal debt held by the public was $\$ 3.8$ tril. the same year. Thus, the total debt was $\$ 12.7$ tril., about 1.6 times the GDP. ${ }^{9}$

Third, our analysis applies to an unfunded social security system in which current benefits and current taxes exactly balance. Much of the recent literature starts from a system in which existing tax rates will not generate sufficient revenues to fund the existing benefit formula in the future. Before applying this section's reform, one must lower benefits to match projected tax revenues, as in (2), or raise taxes to equal statutory benefits, or select some combination of the two. As the next section shows, however, a reform along the lines suggested here conceivably would help to avert future crises of this nature.

\section{Funded vs. Unfunded Social Security}

The previous section outlines an abrupt transition to a funded social security program. The present section lists possible benefits of doing so in practice.

First, Section 1's private accounts might ease young households' worries about the safety of their future benefits; benefits based on government bonds in private accounts presumably would attain the same legal status as all national debt. As the President's Commission [2001,p.16] recently noted, " ... retirement security for Social Security participants will be enhanced by ownership of assets accumulated through the Social Security system, relative to a claim to benefits that must remain subject to political negotiation."

Second, private accounts might form a convenient platform from which to implement further reform, perhaps reform allowing participants somewhat more latitude over their financial investment choices. For example, government might modify mandated behavior for the funded system described above to allow young households freedom to choose to invest some fraction of their private accounts in common stocks or corporate bonds. ${ }^{10}$ The change would be simple since funded accounts would already exist. In fact, it seems possible that voters might be more willing to consider additional reform if they felt their basic benefits were secure in private accounts - recall the quotation in the previous paragraph.

Third, a system of private accounts might change participants' psychology enough to help arrest future growth of the sum of implicit and explicit government liabilities as a fraction of GDP. The existing (implicit) debt from social security reflects the system's

9 For comparison, the explicit debt alone reached a level relative to GDP in 1946 of about 1.1 .

10 See, for example, National Academy of Social Insurance [1999] and Shoven [1999]. 
history. At its inception, the system paid benefits to retirees who had themselves paid few, if any, social security taxes. Subsequent increases in tax and benefit rates raised the debt as well - using Section 1's framework, if factor prices remain constant, raising taxes and benefits increases the debt proportionately — raising the economy's debt/GDP ratio. See Table 6, considering the 1970s in particular.

Increases in benefits and taxes might reflect political sentiment; however, natural forces can lead to changes in the implicit debt as well. The U.S. social security system specifies a benefit formula based on wages, retirement age, etc. If the formula is fixed but rising longevity leads to longer retirements relative to working life, the ratio of the present value of future benefits to current GDP rises (and the system requires higher tax rates). Likewise, if the birth rate falls, the ratio of young to old people declines. Roughly speaking, the GDP depends on the number of working people; aggregate social security benefits depend on the number of retirees. Hence, with a constant benefit formula, again the ratio of the economy's implicit debt relative to the GDP will tend to rise.

A funded system with private accounts might change people's perspective. Suppose, for example, that SSA can predict at time $t$ that young households, and future households, will live longer. And, suppose that households want to devote their extra years to retirement. Then young households at time $t$, and beyond, might vote for larger contributions in youth to their private accounts, taking the new money from their aftertax income. With a clear connection between contributions and benefits, it might seem logical to them to do so. With pre-funding, there would not be an increase in government debt, either explicit or implicit. A standard course of action under the present system, in contrast, would be to do nothing until time $t+1$ and then to increase benefits and taxes simultaneously; since in the latter case old households at $t+1$ receive enhanced benefits without themselves paying higher taxes, the government's implicit liability in Table 5 does rise. ${ }^{11}$

Fourth, Section 1's analysis shows clearly the close connection between unfunded social security liabilities and national debt: they are virtually two different sides of the same coin. Funding the social security system would simplify information problems for voters: instead of having to keep track of two types of government liability, there would be a single one.

\section{Increasing Saving}

The previous sections suggest a way of converting an unfunded social security system to a funded one utilizing a procedure which leaves macroeconomic variables such as the economy's physical capital stock unchanged. In fact, reform advocates frequently suggest that an important goal is to increase the nation's capital stock, and many suggest reforms combining steps to fund social security with others to generate new tax revenues to reduce Table 5's total government liability. Having considered funding the social security system with new government bonds, this paper turns in Section 4 to an analysis of paying down

11 In a related discussion, the President's Commission [2001,p.31] writes, "It is impossible to know with precision the degree to which the federal government would otherwise save Social Security revenues that are to be deposited in personal accounts. The most that can be said is that as a matter of historical record, the government has not tended to save this money." 
the national debt - the strategy being to analyze the total process in the two steps separately, rather than simultaneously. The present section pauses to examine the merit of reducing the debt. Why pay down the national debt? Or, at least, why resist increasing it? This section considers three possible answers, which it labels "morality," "generosity," and "necessity."

James Buchanan [1986] articulates the first. When an economy finances current government services, or transfers, with debt, it is, in effect, passing the cost on to future generations. Buchanan writes,

"The financing of current public consumption by debt issue is unjust because it shifts income from those who are not and cannot be beneficiaries of the outlay and who do not and cannot participate in [the] complex political process that generates the observed results. 'Taxation without representation' is literally descriptive of the plight of those who will face the debt-burden overhang in future periods." [p.188]

The second answer, "generosity," is more subtle. Suppose the present generation cares about the future of its descendants and its country as a whole. If foreigners hold the current national debt, paying it down will relieve the home economy of future obligations for interest and principal. If we limit our attention to closed economies, future generations will owe interest and principal payments only to themselves. Nevertheless, in practice tax revenues come mainly from income and social security taxes. These distort the work and saving incentives of private-sector agents. Economists call the efficiency cost of such distortions deadweight loss. Thus, servicing a national debt creates deadweight loss. If the present generation pays down the national debt, it incurs extra deadweight loss itself (in generating tax revenues to make the payments), but it lessens the deadweight losses society will face in the future. It is also the case that the so-called overlapping generations model (see Section 4), which economists frequently employ to study national debt and social security, typically implies that national debt reduces an economy's ability to accumulate physical capital. If the present generation pays down the national debt, such a model implies the economy will have a larger capital stock in the future, generating a higher gross domestic product. ${ }^{12}$ Again, sacrifice in the present, to pay extra taxes to reduce the public debt, yields benefits in the future.

A number of factors complicate the analysis. A higher interest rate makes generosity more attractive: if $r_{t}$ is the current interest rate, a dollar's worth of national debt reduction now relieves the economy next period of the burden of $1+r_{t}$ dollars of debt principal plus interest. A lower rate of population growth, cet par, tends to help as well. If $n_{t}$ is the rate of population increase, $1+n_{t}$ people next period split the benefits of a dollar's worth of debt reduction this period. A higher rate of technological progress tends to be detrimental to generous impluses. The standard of living tends to rise over time in the U.S. - very substantially in the long run — and economists often attribute much of the change to technological progress - i.e., to growth in knowledge. To the extent that future generations will be better off due to superior technologies, their marginal utility from each dollar reduction in national debt will be lower.

12 According to Auerbach and Kotlikoff [1987, tab.6.1], for instance, adding to the national debt lowers the long-run capital stock roughly one-for-one. 
It seems plausible that a typical household cares more about the future of its own family line than of its society as a whole. Then since a household can provide for its descendants with private bequests, why are public transfers through reductions in national debt attractive? Taxes might provide an explanation. If I save 1 dollar to bequeath, the corporate income tax takes part of the investment return, the personal income tax intercepts part of the interest and dividend return, and estate and inheritance taxes may take part of the principal. The tax collections are not lost to society, but their benefit spills away from my family line. About 50 percent of U.S. households leave bequests - though the fraction with substantial estates is smaller (e.g., Laitner and Ohlsson [2001]). Absent taxes, households desiring to make bequests might constitute a voting majority. Consider a household desiring to leave an estate, or on the borderline of desiring an estate but dissuaded by taxes. If the household votes for reducing the national debt, its descendants will benefit, and, if all family lines participate, the spillovers above may cancel one another out.

"Necessity" may be a reason to resist increases in the national debt. Assessing the magnitude of the deadweight loss from present taxes is a controversial subject (e.g., Feldstein [1995], Moffit and Wilhelm [2000], Blundell and MaCurdy [1999], Lumsdaine and Mitchell [1999], Burkhauser et al. [1999]). However, theory shows that deadweight loss rises with the square of the tax rate. The square rule puts a limit on how high the debt/GDP ratio can go without dramatic repercussions. ${ }^{13}$ A second argument in somewhat the same vein is that is that as the debt ratio climbs, the probability of default grows. Above some ratio, bond markets will no longer accept additional debt.

In conclusion, this sections lists several possible reasons an economy might want to reduce, or control the size of, its national debt. ${ }^{14}$ The next examines what might happen if the economy decides to go ahead.

\section{Reducing Public Debt}

Economists employ two basic frameworks in their dynamic simulations (cited above):

13 Debt service on the present explicit debt alone is substantial - in 1998, for example, the three largest outlays of the U.S. Federal government were social security benefits, $\$ 379$ bil.; national defense, $\$ 268$ bil.; and, net interest on the (explicit) national debt, $\$ 243$ bil.

14 Yet another argument that might be mentioned follows from Keynesian ideas. As outlined above, a society which pays down its national debt may accumulate more physical capital. But, Keynes worried that a large capital stock might exhaust opportunities for business physical investment, creating a shortage of demand for output, leading, in turn, to unemployment and stagnation. E.g., Keynes [1964, p.219]: "It follows that of two equal communities, having the same technique but different stocks of capital, the community with the smaller stock of capital may be able for the time being to enjoy a higher standard of life than the community with the larger stock; though when the poorer community has caught up with the rich ... both alike will suffer the fate of Midas." A second interpretation of Keynesian ideas would be that the process of paying down the national debt would tend to reduce "aggregate demand," possibly requiring attention, say, from monetary policy, to prevent a recession. 
the life-cycle, or overlapping generations, model; and, the dynastic, or altruistic, model. The first assumes that households care exclusively about their own lives, not those of their predecessors or descendants (e.g., Modigliani [1986] and Diamond [1965]). Since a household's earnings typically rise with age until retirement and then decline or disappear, the model predicts that each household's wealth holdings will follow a lifetime cycle as well, rising in youth and middle age as the household saves in anticipation of retirement, and declining thereafter as it dissaves to pay for its retirement. The second is the so-called altruistic model (e.g., Becker [1974] and Barro [1975]). In it, households care about their descendants as well as themselves. Such households may receive inheritances and may save to build estates. There is a longstanding debate within the economics profession about the quantitative importance of bequest-motivated relative to life-cycle saving (e.g., Kotlikoff and Summers [1981], Modigliani [1988]). A second empirical issue concerns the distribution of private wealth: in the U.S., the latter is extremely concentrated (e.g., Wolff [1995]) seemingly much more so than is the case for earnings - and the life-cycle model may not be able to explain the unevenness (e.g., Huggett [1996]). A third issue is that while life spans increased substantially in the U.S. during the twentieth century, and taking a period of retirement at the end of life became much more popular, national wealth accumulation (relative to output) changed very little. The latter outcome does not seem consistent with the life-cycle model, according to which saving should have increased (e.g., Darby [1979]). This section suggests a third framework for analysis, combining the other two, and it examines implications of debt reduction in each of the three models.

Suppose we have a closed economy with a Cobb-Douglas aggregate production function summarizing the business sector:

$$
Q=K^{\alpha} \cdot L^{1-\alpha}, \quad \alpha \in(0,1)
$$

where $Q$ is real GDP, $K$ is the economy's physical capital stock, and $L$ is the labor supply. For simplicity, omit depreciation of physical capital, population growth, and technological progress. Normalize the price of output to one. If $W$ is the steady-state wage rate and $r$ the steady-state interest rate, with competitive factor pricing we have

$$
W \cdot L=(1-\alpha) \cdot Q \text { and } r \cdot K=\alpha \cdot Q
$$

Thus,

$$
\frac{K}{W \cdot L}=\frac{\alpha}{1-\alpha} \cdot \frac{1}{r}
$$

Figures 1-3 graph this relation as the production sector's "demand for capital" curve.

Suppose the economy has only life-cycle saving. In a steady-state equilibrium with both $r$ and $W$ constant, one can derive aggregate desired life-cycle net worth holdings at each $r$. Plotting the latter in units of earnings, one has Figure 1's "supply of net worth" curve $S$. In the frequently used simple case with two period lives and logarithmic utility functions, the supply curve is vertical. In more realistic cases, it could have a negative or positive slope - with the latter being the most typical in existing work. (See, for instance, Tobin [1967].) The initial long-run equilibrium is at $e^{0}$. 
Let the national debt be $D$. Assume society rolls the debt over so that $D / Q$ remains constant through time. The debt might have originated from funding the social security system, as in Section I, or it might have arisen in other ways. Private net worth accumulations must finance both the physical capital stock, $K$, and the national debt. Furthermore, taxes to pay interest on $D$ reduce household lifetime resources, tending to shift $S$ west to $S^{\prime}$. Thus, the steady-state equilibrium interest rate rises from $r^{0}$ to to $r^{1}$, where the supply of private net worth is exactly large enough to cover the national debt and the physical capital stock. Combining (7)-(8),

$$
W=(1-\alpha) \cdot\left[\frac{K}{L}\right]^{\alpha} \text { and } \quad r=\alpha \cdot\left[\frac{K}{L}\right]^{\alpha-1}
$$

Equation (10) shows that the higher steady-state interest rate associated with $D>0$ implies a lower capital-to-labor ratio, $K / L$; a lower steady-state wage; and, a higher output at each date.

A well-know study of debt in this type of framework is Auerbach and Kotlikoff [1987, ch.6]. A reduction in debt can lead to a large increase in the physical capital stock, raising GDP in turn. The latter rise could expedite the debt-reduction program: initial debt reduction would raise output, providing additional resources for future debt repayments.

In the simplest dynastic model — see Barro [1974] — the supply-of-household-wealth curve is horizontal - see $S$ in Figure 2. The idea is that households care about their descendants into the distant future and that first-order conditions for utility-maximization therefore connect marginal utilities over very long time spans. The long time horizons imply that even small changes in the steady-state interest rate have a highly leveraged effect on behavior, leading to a very interest elastic supply curve. The initial long-run equilibrium is at $e^{0}$.

It is easy to see that the shape of Figure 2's $S$ curve makes the steady-state equilibrium interest rate invariant to changes in $D$ : higher taxes, which shift $S$ horizontally leftward, do not, in the end, affect the supply curve's position; households willingly finance debt $D>0$, as opposed to debt 0 , with only an infinitesimal increase in the interest rate. This is one manifestation of Barro's famous "Ricardian equivalence" result. In fact, in the simplest dynastic model debt reduction accomplishes virtually nothing, even in the short run. The equilibrium interest rate remains at $r^{0}$.

Laitner [2001b,c] presents a combined model with four basic elements. First, each household has a life-cycle of earnings and mortality. Second, all households care about their descendants as well as themselves (though in their calculations they may weigh the utility of their descendants less heavily than their own). Third, there is an exogenous distribution of earning abilities in every birth cohort. Fourth, financial institutions do not allow households to have negative net worth, nor can households choose to make negative intergenerational transfers to their descendants. In equilibrium, all households do life-cycle saving and dissaving. On the other hand, low earners, and those without large inheritances, tend to fall at a zero-bequest corner solution, whereas high earners, and/or households with large inheritances, save to build estates as well as for life-cycle purposes. The idea is that low earners expect their descendants to do at least as well as themselves, whereas high earners have more doubts. The combined model therefore dispenses with the 
simple model's unrealistic implication that all, or even most, households leave substantial bequests.

Consider Figure 3. At low interest rates, overall bequest activity is relatively modest, so that $S$ may closely resemble Figure 1 . At higher prospective interest rates, on the other hand, long time horizon dynastic transfers become more appealing, so that bequests become more important - thus, the supply of net worth expands and it becomes more interest elastic. In fact, Laitner [2001c] shows mathematically that the combined model's supply curve must asymptotically approach Barro's curve.

In Laitner's [2001c] calibration, the hybrid model's long-run equilibrium occurs at a point resembling $e$ in Figure 3, in the supply curve's flat section.

In terms of empirical evidence, Figure 3 hints that the hybrid model can be consistent with the U.S. economy's large stock of private net worth without requiring unrealistically high interest rates. In Laitner's [2001c] calibration, estate building accounts for about 30 percent of private wealth. Other recent work studying different motives for bequests seems to arrive at similar fractions (e.g., Altig et al. [2001]).

The calibrated hybrid model is consistent with the high concentration of U.S. wealth as well - see Laitner [2001c, tab.6]. In the model, all households accumulate net worth to finance their retirement, but high earners save extra to share with their descendants. The latter saving tends to raise the concentration of the cross-sectional distribution of private wealth holdings. ${ }^{15}$

Laitner [2001a] suggests that a combination model can also be broadly consistent with U.S. twentieth century history. Consider Figure 4. Early in the century, a long retirement was rare. Thus, the contribution of life-cycle saving - i.e., the relatively steep part of the supply curve - might have been small. When retirement played a greater role later, the supply curve may have been at $S^{\prime}$. The long-run interest rate need not have changed appreciably, however, as the figure illustrates: the old long-run equilibrium was at $e_{1900}$, and the new one is at $e_{2000}$.

Returning to Figure 3, an equilibrium at $f$ would imply policy implications for national debt similar to the life-cycle model; an equilibrium at $e$ would suggest outcomes more closely resembling Barro's [1974]. In fact, as stated, Laitner's calibration points to an intersection at $e$.

With an equilibrium at $e$, a program of debt reduction would not ultimately lead to a sizable reduction in interest rates or a substantial increase in the physical capital stock. Unlike Barro, there would be short-run adjustments, however. And, for the same reason, the long-run distribution of wealth would change: households planning substantial bequests give Figure 3's supply curve its high interest elasticity; following a reduction in $D$, the same households (i.e., the elastic ones) would be the ones, according to the model, to reduce their portfolio sizes. Since the bequeathers are the high accumulators, that would tend to make the distribution of wealth more equal (see Laitner [2001a]).

15 Gokhale et al. [2001] and Nishiyama [2001] present alternative hybrid models which can also explain a high degree of wealth inequality. See the discussion of different models in Laitner [2002]. 


\section{Conclusion}

Section 1 of this paper suggests that the U.S. social security system could be reformed from an unfunded to a funded system virtually instantaneously through the use of government debt. Such a reform would have almost no direct economic consequences. It might nevertheless be significant: it might change society's psychology with regard to coping with future demographic trends, it might help to clarify for voters the full extent of the burden of the economy's indebtedness, and it might facilitate future additional reforms.

While proposed reforms usually include provisions for new tax revenues, this paper suggests splitting the task into two parts: funding the system through national debt, and then paying down the national debt. Section 3 examines possible rationales for proceeding to the second step.

Section 4 catalogs different macroeconomic implications of debt reduction for different modeling frameworks. In all cases, paying down the debt reduces the tax burden on future generations. In some cases, it leads as well to a substantial long-run increase in the economy's stock of physical capital and, hence, potential output. Other models predict more modest changes in economic variables, perhaps with reductions in the inequality of private wealth holdings. 


\section{Bibliography}

[1] Abel, A., Mankiw, N., Summers, L., and Zeckhauser, R., "Assessing Dynamic Efficiency," Review of Economic Studies 56, no. 1 (January 1989), pages 1-19.

[2] Altig, David, Auerbach, Alan J., Kotlikoff, Laurence J., Smetters, Kent A., and Walliser, Jan, "Simulating Fundamental Tax Reform in the United States," American Economic Review, 91, no. 3 (June 2001), 574-595.

[3] Auerbach, A., and Kotlikoff, L., Dynamic Fiscal Policy. Cambridge, U.K.: Cambridge University Press, 1987.

[4] Barro, R.J., "Are Government Bonds Net Worth?" Journal of Political Economy 82, no. 6 (December 1974): 1095-1117.

[5] Becker, G.S., "A Theory of Social Interactions," Journal of Political Economy 82, no. 6 (November/December 1974): 1063-1093.

[6] Blundell, Richard, and MaCurdy, Thomas, "Labor Supply: A Review of Alternative Approaches," in Orley Ashenfelter and David Card (eds.), Handbook of Labor Economics: vol.3A. Amsterdam: Elsevier, 1999.

[7] Buchanan, James M., "Budgetary Bias in Post-Keynesian Politics: the Erosion and Potential Replacement of Fiscal Norms," in Buchanan, Rowley, and Tollison (eds.), Deficits. Oxford: Basil Blackwell, 1986.

[8] Burkhauser, Richard V., Dwyer, Debra, Lindeboom, Maarten, Theeuwes, Jules, and Woittiez, Isolde, "Health, Work, and Economic Well-Being of Older Workers, Aged Fifty-One to Sixty-One: A Cross-National Comparison Using the U.S. HRS and the Netherlands CERRA Data Sets," in James P. Smith and Robert Willis (eds.), Wealth, Work, and Health: Innovations in Measurement in the Social Sciences. Ann Arbor: The University of Michigan Press, 1999.

[9] Darby, M.R. The Effects of Social Security on Income and the Capital Stock. Washington, D.C.: American Enterprise Institute, 1979.

[10] Diamond, P.A., "National Debt in a Neoclassical Growth Model," American Economic Review 55, no. 5 (December 1965): 1126-1150.

[11] Feldstein, Martin S., "The Effect of Marginal Tax Rates on Taxable Income," Journal of Political Economy 103, no. 3 (June 1995): 551-572.

[12] Feldstein, Martin S., "Introduction," in Feldstein, M., Ed, Privatizing Social Security. Chicago: The University of Chicago Press, 1998.

[13] Feldstein, Martin S., and Samwick, Andrew, "The Economics of Prefunding Social Security and Medicare Benefits," in Bernanke, Ben S., and Rotemberg, Julio J., NBER Macroeconomics Annual 1997. Cambridge: The MIT Press, 1997.

[14] Feldstein, Martin S., and Samwick, Andrew, "The Transition Path in Privatizing Social Security," in Feldstein, M., Ed, Privatizing Social Security. Chicago: The University of Chicago Press, 1998.

[15] Huggett, M., "Wealth Distribution in Life-Cycle Economies," Journal of Monetary Economics 38 (1996): 469-494. 
[16] Geanakoplos, John, Mitchell, Olivia S., and Zeldes, Stephen P., "Social Security Money's Worth," in Mitchell, Olivia S., Myers, Robert J., and Young, Howard (eds.), Propects for Social Security Reform. Philadelphia: University of Pennsylvania Press, 1999.

[17] Gokhale, Jagadeesh, Kotlikoff, Laurence J., Sefton, James, and Weale, Martin, "Simulating the Transmission of Wealth Inequality Via Bequests," Journal of Public Economics 79, no. 1 (January 2001), 93-128.

[18] Keynes, John M. The General Theory of Employment, Interest, and Money. New York: Harcourt, Brace, and World, Inc., 1964.

[19] Kocherlakota, Narayana R., "The Equity Premium: It's Still a Puzzle," Journal of Economic Literature XXXIV (1), March 1996, 42-71.

[20] Kotlikoff, L.J., "Simulating the Privatization of Social Security in General Equilibrium," in Feldstein, M., Ed, Privatizing Social Security. Chicago: The University of Chicago Press, 1998.

[21] Kotlikoff, L.J., and Summers, L., "The Role of Intergenerational Transfers in Aggregate Capital Accumulation," Journal of Political Economy 89, no. 4 (August 1981): 706-732.

[22] Laitner, J., "Tax Changes and Phase Diagrams for an Overlapping Generations Model," Journal of Political Economy 98, no. 1 (February 1990): 193-220.

[23] Laitner, John, "Secular Changes in Wealth Inequality and Inheritance," The Economic Journal, 111, no.474 (October 2001a): 691-721.

[24] Laitner, John, "Simulating the Effects on Inequality and Wealth Accumulation of Eliminating the Federal Gift and Estate Tax," in Gale and Slemrod (eds.), Rethinking Estate and Gift Taxation. Washington, D.C.: The Brookings Institution, 2001b.

[25] Laitner, John, "Wealth Accumulation in the U.S.: Do Inheritances and Bequests Play a Significant Role?" Mimeo, The University of Michigan, 2001c.

[26] Laitner, John, "Wealth Inequality and Altruistic Bequests," American Economic Review, to appear 2002.

[27] Laitner, John, and Ohlsson, Henry, "Bequest Motives: A Comparison of Sweden and the United States," Journal of Public Economics, 79, no. 1 (January 2001): 205-236.

[28] Lumsdaine, Robin L., and Mitchell, Olivia S., "New Developments in the Economic Analysis of Retirement," in Orley Ashenfelter and David Card (eds.), Handbook of Labor Economics: vol.3C. Amsterdam: Elsevier, 1999.

[29] Modigliani, F., "Life Cycle, Individual Thrift, and the Wealth of Nations," American Economic Review 76, no. 3 (June 1986): 297-313.

[30] Modigliani, F., "The Role of Intergenerational Transfers and Life Cycle Saving in the Accumulation of Wealth," Journal of Economic Perspectives 2, no. 2 (Spring 1988): $15-14$.

[31] Moffit, Robert A., and Wilhem, Mark O., "Taxation and the Labor Supply Decisions of the Affluent," in Joel B. Slemrod (ed.), Does Atlas Shrug? The Economic Consequences of Taxing the Rich. New York: Russell Sage Foundation, 2000. 
[32] Nishiyama, Shinichi, "Measuring time preference and parental altruism." Mimeo, Congressional Budget Office, Washington, D.C., 2001.

[33] National Academy of Social Insurance, Diamond, Peter A. (ed.), Issues in Privatizing Social Security. Cambridge: MIT Press, 1999.

[34] President's Commission, "Strengthening Social Security and Creating Personal Wealth for All Americans." 12-11-01.

[35] Shoven, John B., "Social Security Reform: Two Tiers Are Better Than One," in Friedman, Benjamin M. (ed.), Should the United States Privatize Social Security? Cambridge: MIT Press, 1999.

[36] Tobin, J., "Life Cycle Saving and Balanced Growth," in Fellner, W., ed, Ten Economic Studies in the Tradition of Irving Fisher. New York: Wiley, 1967.

[37] Wolff, E.N., Top Heavy: A Study of Increasing Inequality of Wealth in America. New York: Twentieth Century Fund Press, 1995.

[38] U.S. Social Security Administration, Annual Statistical Supplement, 2001. Washington: Social Security Administration, 2001. 


\section{Appendix 1}

Unfunded Social Security.

Each household lives two periods, and a household born at $t$ has utility function

$$
\theta \cdot \ln \left(c_{t}^{1}\right)+(1-\theta) \cdot \ln \left(c_{t}^{2}\right),
$$

where $c^{i}$ is consumption in period of life $i=1,2$. A household supplies one unit of labor in youth and none in old age. The gross-of-tax wage is $W_{t}$. The social security tax falls on wages and has rate $\tau^{s s}$. There is a proportional income tax of rate $\tau$ on wages and return to saving. The net-of-tax rate of return on saving is $r_{t}$.

There is an aggregate production function

$$
Q_{t}=\left[K_{t}\right]^{\alpha} \cdot\left[L_{t} \cdot(1+g)^{t}\right]^{1-\alpha}, \quad \alpha \in(0,1) .
$$

Technological progress, with rate $g>0$, augments the effectiveness of labor. The GDP is $Q_{t}$, and the physical capital stock is $K_{t}$. The labor supply is $L_{t}$. For simplicity, assume

$$
L_{t}=(1+n)^{t} .
$$

Set the price of units of GDP to 1 every period. Competitive factor pricing leads to

$$
\begin{aligned}
& W_{t}=(1-\alpha) \cdot\left[K_{t}\right]^{\alpha} \cdot\left[L_{t} \cdot(1+g)^{t}\right]^{-\alpha} \cdot(1+g)^{t}, \\
& r_{t}=\alpha \cdot\left[K_{t}\right]^{\alpha-1} \cdot\left[L_{t} \cdot(1+g)^{t}\right]^{1-\alpha} \cdot(1-\tau)-\delta,
\end{aligned}
$$

where $\delta$ is the rate of physical depreciation on capital and where income taxes fall on the marginal physical product of capital. To simplify the formulas below, we set

$$
\delta=1 .
$$

Government spends income tax revenues on goods and services (e.g., defense). The social security system is unfunded: if a household born at $t$ receives benefit $b_{t+1}$ in old age,

$$
\tau^{s s} \cdot W_{t+1} \cdot L_{t+1}=b_{t+1} \cdot L_{t} .
$$

"Equilibrium" requires that households maximize their individual well-being given factor prices and their endowment, and that household net worth finances the physical capital stock. (The economy is closed to international trade and capital flows.)

In equilibrium, a household born at $t$ solves

$$
\max _{c_{t}^{1}, c_{t}^{2}}\left\{\theta \cdot \ln \left(c_{t}^{1}\right)+(1 \theta) \cdot \ln \left(c_{t}^{2}\right)\right\}
$$

subject to: $\quad c_{t}^{1}+\frac{c_{t}^{2}}{1+r_{t+1}} \leq W_{t} \cdot\left(1-\tau-\tau^{s s}\right)+\frac{b_{t+1}}{1+r_{t+1}}$.

Maximization yields 


$$
\begin{gathered}
c_{t}^{1}=\theta \cdot\left[W_{t} \cdot\left(1-\tau-\tau^{s s}\right)+\frac{b_{t+1}}{1+r_{t+1}}\right] \\
C_{t}^{2}=(1-\theta) \cdot\left[W_{t} \cdot\left(1-\tau-\tau^{s s}\right)+\frac{b_{t+1}}{1+r_{t+1}}\right] \cdot\left(1+r_{t+1}\right) .
\end{gathered}
$$

The net worth such a household chooses to carry into its second period of life equals its first-period aftertax income less its first-period consumption:

$$
a_{t} \equiv(1-\theta) \cdot W_{t} \cdot\left(1-\tau-\tau^{s s}\right)-\theta \cdot \frac{b_{t+1}}{1+r_{t+1}} .
$$

The second part of the definition of equilibrium requires

$$
K_{t+1}=L_{t} \cdot a_{t}
$$

Define

$$
E_{t} \equiv L_{t} \cdot(1+g)^{t} \quad \text { and } \quad k_{t} \equiv \frac{K_{t}}{E_{t}}
$$

Then

$$
\begin{gathered}
k_{t+1}=\frac{L_{t} \cdot a_{t}}{E_{t+1}}=\frac{(1+n)^{t} \cdot a_{t}}{(1+n)^{t+1} \cdot(1+g)^{t+1}}= \\
\frac{1}{1+n} \cdot\left(\frac{1}{1+g}\right)^{t+1} \cdot\left[(1-\theta) \cdot(1-\alpha) \cdot\left[K_{t}\right]^{\alpha} \cdot\left[E_{t}\right]^{-\alpha} \cdot(1+g)^{t} \cdot\left(1-\tau-\tau^{s s}\right)-\right. \\
\left.\frac{\theta \cdot(1+n) \cdot(1-\alpha) \cdot\left[K_{t+1}\right]^{\alpha} \cdot\left[E_{t+1}\right]^{-\alpha} \cdot(1+g)^{t+1} \cdot \tau^{s s}}{1+(1-\tau) \cdot \alpha \cdot\left[K_{t+1}\right]^{\alpha-1} \cdot\left[E_{t+1}\right]^{1-\alpha}-\delta}\right] .
\end{gathered}
$$

So,

$$
\begin{aligned}
k_{t+1}= & \frac{1}{1+n} \cdot \frac{1}{1+g} \cdot(1-\alpha) \cdot\left[(1-\theta) \cdot\left[k_{t}\right]^{\alpha} \cdot\left(1-\tau-\tau^{s s}\right)-\right. \\
& \left.\frac{\theta \cdot(1+n) \cdot\left[k_{t+1}\right]^{\alpha} \cdot(1+g) \cdot \tau^{s s}}{(1-\tau) \cdot \alpha \cdot\left[k_{t+1}\right]^{\alpha-1}}\right] .
\end{aligned}
$$

So,

$$
k_{t+1} \cdot\left[1+\frac{\theta \cdot(1-\alpha) \cdot \tau^{s s}}{\alpha \cdot(1-\tau)}\right]=\frac{1}{1+n} \cdot \frac{1}{1+g} \cdot(1-\alpha) \cdot(1-\theta) \cdot\left(1-\tau-\tau^{s s}\right) \cdot\left[k_{t}\right]^{\alpha}
$$

If the analysis begins at time 0 , history must provide our starting value $k_{0}$. Then we can iterate $\mathrm{A}(16)$ to determine the equilibrium path $k_{t}$ all $t$. 


\section{Funded Social Security.}

The model is as before, except that we now fund social security, using national debt as described in the text. Make the reform to a funded social security system at time $t=0$.

The generation old at time 0 is unaffected.

Consider the generation young at time 0 . Setting $t=0$, its lifetime budget constraint is still

$$
c_{t}^{1}+\frac{c_{t}^{2}}{1+r_{t+1}} \leq W_{t} \cdot\left(1-\tau-\tau^{s s}\right)+\frac{b_{t+1}}{1+r_{t+1}} .
$$

However, the last term on the right now represents government transfers at time 0 , rather than the present value of future social security benefits. Utility-maximizing consumption remains as before - since lifetime resources are as before. The contemporaneous nature of the last term in the budget changes a household's net worth carried to period 1 to

$$
a_{t} \equiv(1-\theta) \cdot\left[W_{t} \cdot\left(1-\tau-\tau^{s s}\right)+\frac{b_{t+1}}{1+r_{t+1}}\right]
$$

(where $t=0$ in the formula).

Since there is now government debt, say, $D_{t}$ carried into period $t$, the second part of the definition of equilibrium changes: household net worth must finance both the physical capital stock and the government debt. Hence, we need

$$
D_{t+1}+K_{t+1}=L_{t} \cdot a_{t} \quad \text { all } \quad t
$$

in place of (A12).

The equation for the evolution of $k_{t}$ remains unchanged at time $t=0$. To see this, note that the nature of our social security reform implies

$$
D_{t+1}=L_{t} \cdot \frac{b_{t+1}}{1+r_{t+1}} \quad \text { all } \quad t .
$$

Subtracting the left-hand side of (A19) from the left of (A18), and the right-hand side of (A19) from the right of (A18), we recover (A11)-(A12) - ie, (A16).

Consider a generation young at $t>1$. Such a household's lifetime budget constraint is

$$
c_{t}^{1}+\frac{c_{t}^{2}}{1+r_{t+1}} \leq W_{t} \cdot(1-\tau)-\left[\tau^{s s} \cdot W_{t}-\frac{b_{t+1}}{1+r_{t+1}}\right] .
$$

In terms of lifetime resources, this is equivalent to the original constraint in (A8). However, the [.] term on the right-hand side is a tax due in youth. With identical lifetime resources, the household chooses the same consumption as before - i.e., (A9)-(A10). The contemporaneous nature of the new tax means the household's net worth carried into old age is as in (A17). But, $\mathrm{A}(18)$ and (A19) continue to hold. Thus, as at time $t=0$, we continue to recover (A11)-(A12), hence (A16).

Thus, the evolution of $k_{t}$ remains as before the reform. Hence, factor prices do not change either. 


\section{Appendix 2}

Suppose we fund social security at time $t=0$, as in the second part of Appendix 1 . Suppose, however, that government places bonds paying interest rate $R$ in the new private accounts, with $R$ not necessarily equal to the current market interest rate. ${ }^{16}$

As before, the generation old at time 0 is unaffected.

A household in the generation young at time 0 now has lifetime budget constraint

$$
c_{t}^{1}+\frac{c_{t}^{2}}{1+r_{t+1}} \leq W_{t} \cdot\left(1-\tau-\tau^{s s}\right)+\frac{b_{t+1}}{1+R}+\left[\frac{b_{t+1}}{1+r_{t+1}}-\frac{b_{t+1}}{1+R}\right] .
$$

The middle term on the right side equals government transfers when the system is funded. The sum arrives at $t=0$. The last term on the right reflects the (possible) discrepancy between the present value at $t=0$ of the government transfer and the actual value at expiration of the bonds the government transfers into the household's private account. The household realizes this sum at $t=1$. Notice that the value of the household's lifetime resources are identical to (A8). Thus, its consumption remains as in (A9)-(A10).

A household young at time $t>0$ has lifetime budget constraint

$$
c_{t}^{1}+\frac{c_{t}^{2}}{1+r_{t+1}} \leq W_{t} \cdot(1-\tau)-\left[\tau^{s s} \cdot W_{t}-\frac{b_{t+1}}{1+R}\right]+\left[\frac{b_{t+1}}{1+r_{t+1}}-\frac{b_{t+1}}{1+R}\right] .
$$

Such a household no longer faces traditional social security taxes. However, the middle term on the right reflects its new debt-service tax. This tax is due at time $t$. The last term on the right is as in (A20). It falls at $t+1$. Notice that lifetime resources remain the same as (A8). Thus, consumption will remain as in (A9)-(A10).

With either (A21) or (A22), we have

$$
a_{t}=(1-\theta) \cdot\left[W_{t} \cdot\left(1-\tau-\tau^{s s}\right)+\frac{b_{t+1}}{1+R}\right]-\theta \cdot\left[\frac{b_{t+1}}{1+r_{t+1}}-\frac{b_{t+1}}{1+R}\right] .
$$

Equation (A18) remains valid, but we need

$$
D_{t+1}=L_{t} \cdot \frac{b_{t+1}}{1+R} \quad \text { all } \quad t
$$

in place of (A19).

As in the second part of Appendix 1, we subtract the right side of (A23) from the right of (A18), and the left side of (A23) from the left of (A18), then we substitute from (A22). We end up with

$$
K_{t+1}=L_{t} \cdot\left\{(1-\theta) \cdot W_{t} \cdot\left(1-\tau-\tau^{s s}\right)-\theta \cdot \frac{b_{t+1}}{1+R}-\theta \cdot\left[\frac{b_{t+1}}{1+r_{t+1}}-\frac{b_{t+1}}{1+R}\right]\right\} .
$$

16 We assume $R$ is constant with respect to time. The reader will be able to see that is not essential, however. 
Canceling like terms on the right-hand side yields

$$
K_{t+1}=L_{t} \cdot\left\{(1-\theta) \cdot W_{t} \cdot\left(1-\tau-\tau^{s s}\right)-\theta \cdot \frac{b_{t+1}}{1+r_{t+1}}\right\},
$$

which is identical to (A11)-(A12). Hence, (A16) remains valid.

In other words, if government sets a non-market interest rate on the bonds in private social security accounts, and if those accounts are mandatory, the time path for $K_{t}$ is unchanged from the reform with market interest rates. 


\begin{tabular}{|c|c|c|c|c|}
\hline \multicolumn{5}{|c|}{ Table 1. Old Regime: Household Taxes and Government Transfers } \\
(per young household) \\
\hline Cohort Birth
\end{tabular}




\begin{tabular}{|c|c|c|c|c|}
\hline \multicolumn{6}{|c|}{ Table 1'. New Regime: Household Taxes and Government Transfers } \\
(per young household) \\
\hline YR & SST & Debt Service & Transfer & SSB \\
(present value)
\end{tabular}




\begin{tabular}{|c|c|c|}
\hline \multicolumn{2}{|c|}{ Table 2. Old Regime: Household Private Account Transactions } \\
(per young household)
\end{tabular}




\begin{tabular}{|c|c|c|}
\hline \multicolumn{2}{|c|}{ Table 2'. New Regime: Household Private Account Transactions } \\
(per young household)
\end{tabular}


Table 3. Old Regime: Government Flows

\begin{tabular}{|c|c|c|c|c|c|c|}
\hline & \multicolumn{2}{|c|}{ Transfers } & \multicolumn{2}{c|}{ Taxes } & \\
\cline { 2 - 6 } YR & SSB & Bonds & $\begin{array}{c}\text { Interest } \\
\text { on Debt }\end{array}$ & SST & $\begin{array}{c}\text { Debt } \\
\text { Service }\end{array}$ & $\begin{array}{c}\text { Debt } \\
\text { Change }\end{array}$ \\
\hline 0 & $B_{0}$ & 0 & 0 & $T_{0}$ & 0 & 0 \\
\hline 1 & $B_{1}=B_{0} \cdot(1+g)$ & 0 & 0 & $T_{1}=T_{0} \cdot(1+g)$ & 0 & 0 \\
\hline 2 & $B_{2}=B_{0} \cdot(1+g)^{2}$ & 0 & 0 & $T_{2}=T_{0} \cdot(1+g)^{2}$ & 0 & 0 \\
\hline 3 & $B_{3}=B_{0} \cdot(1+g)^{3}$ & 0 & 0 & $T_{3}=T_{0} \cdot(1+g)^{3}$ & 0 & 0 \\
\hline
\end{tabular}




\begin{tabular}{|c|c|c|c|c|c|c|}
\hline & & & Table $3^{\prime}$. Ner & egim & Government Flows & \\
\hline \multirow[b]{2}{*}{ YR } & \multicolumn{3}{|c|}{ Transfers } & \multicolumn{2}{|r|}{ Taxes } & \multirow[b]{2}{*}{$\begin{array}{c}\text { Debt } \\
\text { Change }\end{array}$} \\
\hline & SSB & Bonds & $\begin{array}{l}\text { Interest } \\
\text { on Debt }\end{array}$ & $\mathrm{SST}$ & $\begin{array}{c}\text { Debt } \\
\text { Service }\end{array}$ & \\
\hline 0 & $B_{0}$ & $\begin{array}{c}\frac{B_{1}}{1+r}= \\
B_{0} \cdot \frac{1+g}{1+r}\end{array}$ & 0 & $T_{0}$ & 0 & $\begin{array}{c}\frac{B_{1}}{1+r}= \\
B_{0} \cdot \frac{1+g}{1+r}\end{array}$ \\
\hline 1 & 0 & 0 & $\begin{array}{c}\frac{r \cdot B_{1}}{1+r}= \\
r \cdot B_{0} \cdot \frac{1+g}{1+r}\end{array}$ & 0 & $\begin{array}{c}T_{1}-\frac{B_{2}}{1+r}= \\
B_{0} \cdot\left[(1+g)-\frac{(1+g)^{2}}{1+r}\right]\end{array}$ & $\begin{array}{c}\frac{B_{2}}{1+r}-\frac{B_{1}}{1+r}= \\
B_{0} \cdot\left[\frac{(1+g)^{2}}{1+r}-\frac{1+g}{1+r}\right]\end{array}$ \\
\hline 2 & 0 & 0 & $\begin{array}{c}\frac{r \cdot B_{2}}{1+r}= \\
r \cdot B_{0} \cdot \frac{(1+g)^{2}}{1+r}\end{array}$ & 0 & $\begin{array}{c}T_{2}-\frac{B_{3}}{1+r}= \\
B_{0} \cdot\left[(1+g)^{2}-\frac{(1+g)^{3}}{1+r}\right]\end{array}$ & $\begin{array}{c}\frac{B_{3}}{1+r}-\frac{B_{2}}{1+r}= \\
B_{0} \cdot\left[\frac{(1+g)^{3}}{1+r}-\frac{(1+g)^{2}}{1+r}\right]\end{array}$ \\
\hline 3 & 0 & 0 & $\begin{array}{c}\frac{r \cdot B_{3}}{1+r}= \\
r \cdot B_{0} \cdot \frac{(1+g)^{3}}{1+r}\end{array}$ & 0 & $\begin{array}{c}T_{3}-\frac{B_{4}}{1+r}= \\
B_{0} \cdot\left[(1+g)^{3}-\frac{(1+g)^{4}}{1+r}\right]\end{array}$ & $\begin{array}{c}\frac{B_{4}}{1+r}-\frac{B_{3}}{1+r}= \\
B_{0} \cdot\left[\frac{(1+g)^{4}}{1+r}-\frac{(1+g)^{3}}{1+r}\right]\end{array}$ \\
\hline
\end{tabular}




\begin{tabular}{|c|c|c|c|}
\hline \multicolumn{2}{|l|}{ Table 4. Incremental Investment and Saving Following Regime Change } \\
(per young household) \\
\hline YR & Investment & Household Saving & National Income and Product Saving \\
\cline { 2 - 4 } & 0 & $\frac{B_{1}}{1+r}$ & $\begin{array}{c}\text { Government } \\
\text { Budget Surplus }\end{array}$ \\
\hline 0 & 0 & $\frac{B_{2}}{1+r}-\frac{B_{1}}{1+r}$ & $-\left[\frac{B_{1}}{1+r}-\frac{B_{1}}{1+r}\right]$ \\
\hline 1 & 0 & $\frac{B_{3}}{1+r}-\frac{B_{2}}{1+r}$ & $-\left[\frac{B_{3}}{1+r}-\frac{B_{2}}{1+r}\right]$ \\
\hline 3 & 0 & $\frac{B_{4}}{1+r}-\frac{B_{3}}{1+r}$ & $-\left[\frac{B_{4}}{1+r}-\frac{B_{3}}{1+r}\right]$ \\
\hline
\end{tabular}




\begin{tabular}{|c|c|c|c|}
\hline \multicolumn{4}{|c|}{$\begin{array}{c}\text { Table 5. Government Debt } \\
\text { (end of year, per young household) }\end{array}$} \\
\hline YR & Implicit Debt & Explicit Debt & Total \\
\hline \multicolumn{4}{|c|}{ Prior to Regime Change } \\
\hline 0 & $\frac{B_{1}}{1+r}=B_{0} \cdot \frac{1+g}{1+r}$ & 0 & $\frac{B_{1}}{1+r}=B_{0} \cdot \frac{1+g}{1+r}$ \\
\hline 1 & $\frac{B_{2}}{1+r}=B_{0} \cdot \frac{(1+g)^{2}}{1+r}$ & 0 & $\frac{B_{2}}{1+r}=B_{0} \cdot \frac{(1+g)^{2}}{1+r}$ \\
\hline 2 & $\frac{B_{3}}{1+r}=B_{0} \cdot \frac{(1+g)^{3}}{1+r}$ & 0 & $\frac{B_{3}}{1+r}=B_{0} \cdot \frac{(1+g)^{3}}{1+r}$ \\
\hline 3 & $\frac{B_{4}}{1+r}=B_{0} \cdot \frac{(1+g)^{4}}{1+r}$ & 0 & $\frac{B_{4}}{1+r}=B_{0} \cdot \frac{(1+g)^{4}}{1+r}$ \\
\hline \multicolumn{4}{|c|}{ After Regime Change } \\
\hline 0 & 0 & $\frac{B_{1}}{1+r}=B_{0} \cdot \frac{1+g}{1+r}$ & $\frac{B_{1}}{1+r}=B_{0} \cdot \frac{1+g}{1+r}$ \\
\hline 1 & 0 & $\frac{B_{2}}{1+r}=B_{0} \cdot \frac{(1+g)^{2}}{1+r}$ & $\frac{B_{2}}{1+r}=B_{0} \cdot \frac{(1+g)^{2}}{1+r}$ \\
\hline 2 & 0 & $\frac{B_{3}}{1+r}=B_{0} \cdot \frac{(1+g)^{3}}{1+r}$ & $\frac{B_{3}}{1+r}=B_{0} \cdot \frac{(1+g)^{3}}{1+r}$ \\
\hline 3 & 0 & $\frac{B_{4}}{1+r}=B_{0} \cdot \frac{(1+g)^{4}}{1+r}$ & $\frac{B_{4}}{1+r}=B_{0} \cdot \frac{(1+g)^{4}}{1+r}$ \\
\hline
\end{tabular}




\begin{tabular}{|c|c|c|}
\hline \multicolumn{2}{|c|}{ Table 6. U.S. Social Security Benefit and } \\
Tax Rates (percent) \\
\hline Year & $\begin{array}{c}\text { Ratio Ave. Benefit } \\
\text { to Ave. Earnings }\end{array}$ & Tax Rate \\
\hline 1940 & 26.9 & 2.0 \\
\hline 1950 & 23.1 & 3.0 \\
\hline 1960 & 24.3 & 6.0 \\
\hline 1970 & 24.8 & 12.6 \\
\hline 1980 & 34.8 & 15.3 \\
\hline 1990 & 35.7 & \\
\hline 2000 & 32.5 & \\
\hline
\end{tabular}

Source: U.S. Social Security Administration [2001].

Column 1: Tab 5.C2, col. 1, and 4.B1, col. 7.

Column 2: Tab. 2.A3, col. 3. 


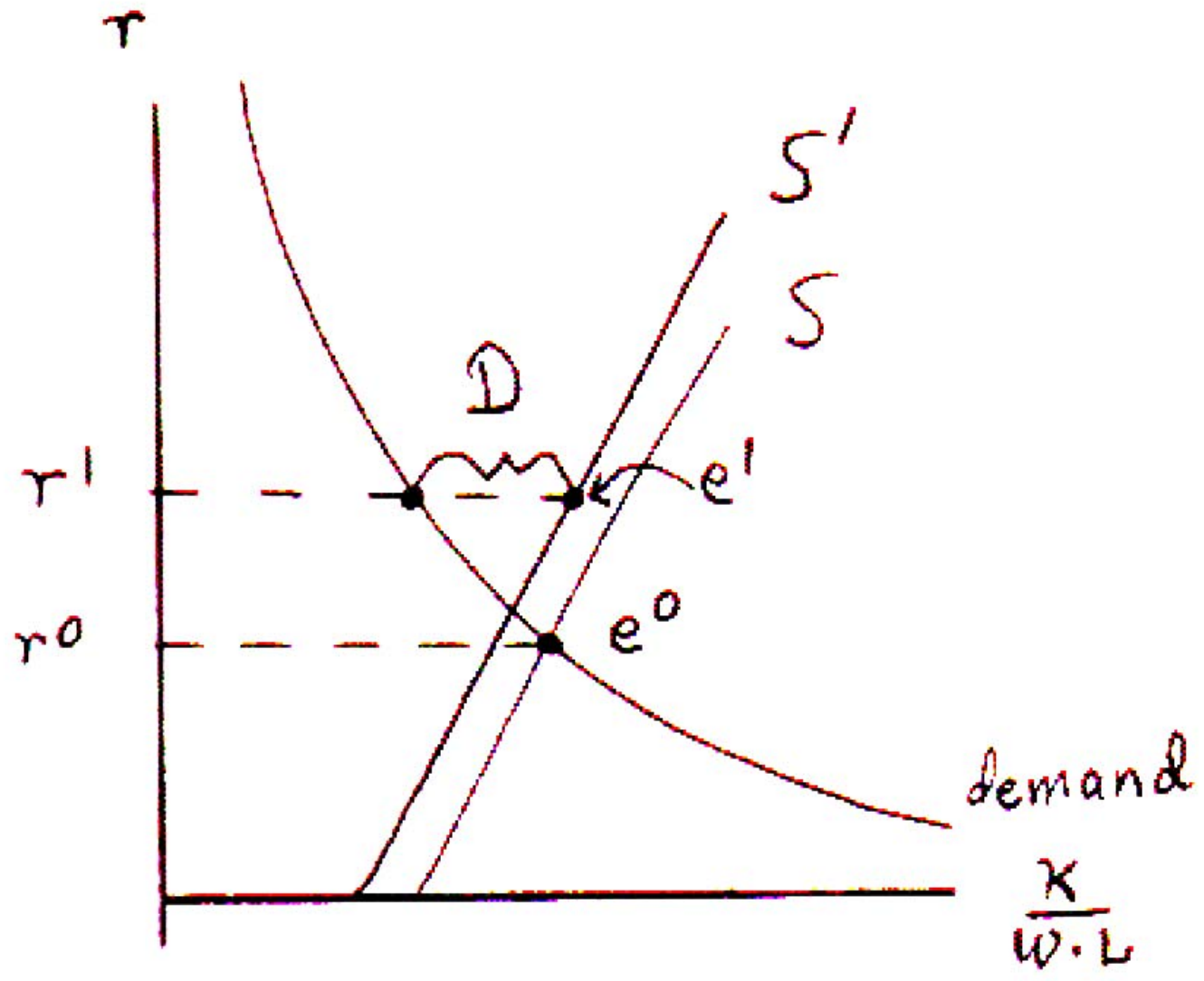

Figure 1. The life-cycle, or overlapping generations, model 


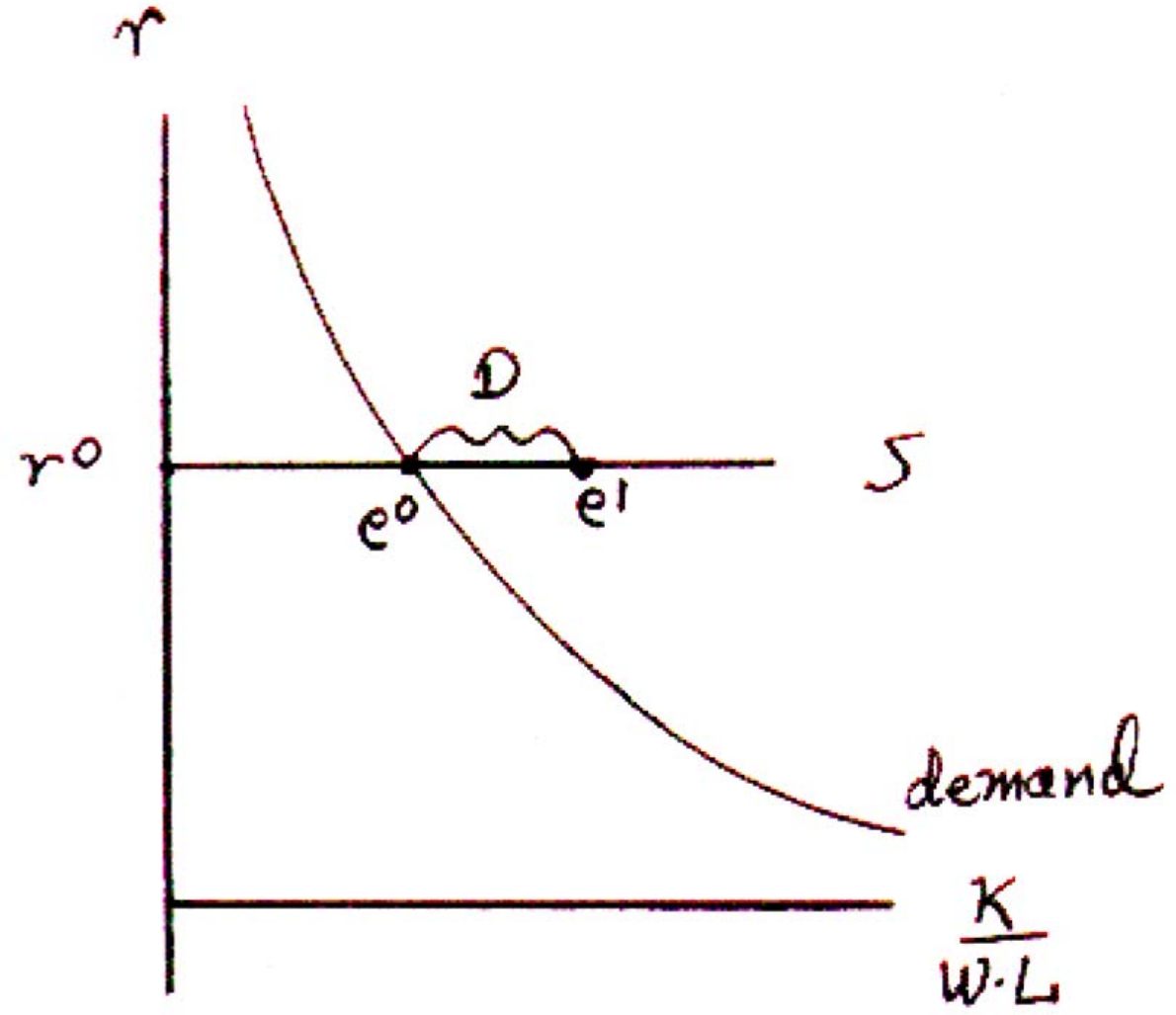

Figure 2. The simplest dynastic model 


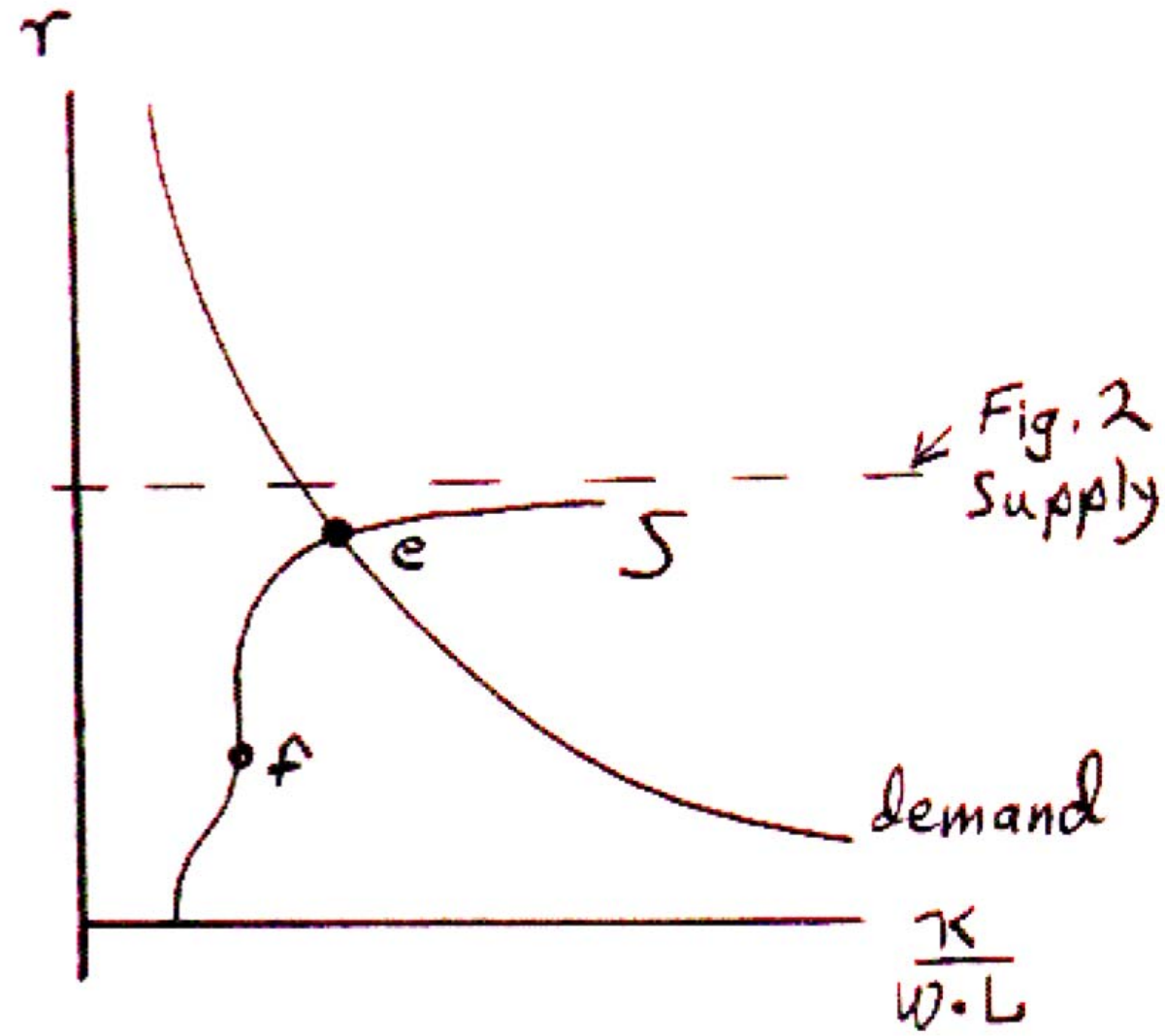

Figure 3. The hybrid dynatic, life cycle model 


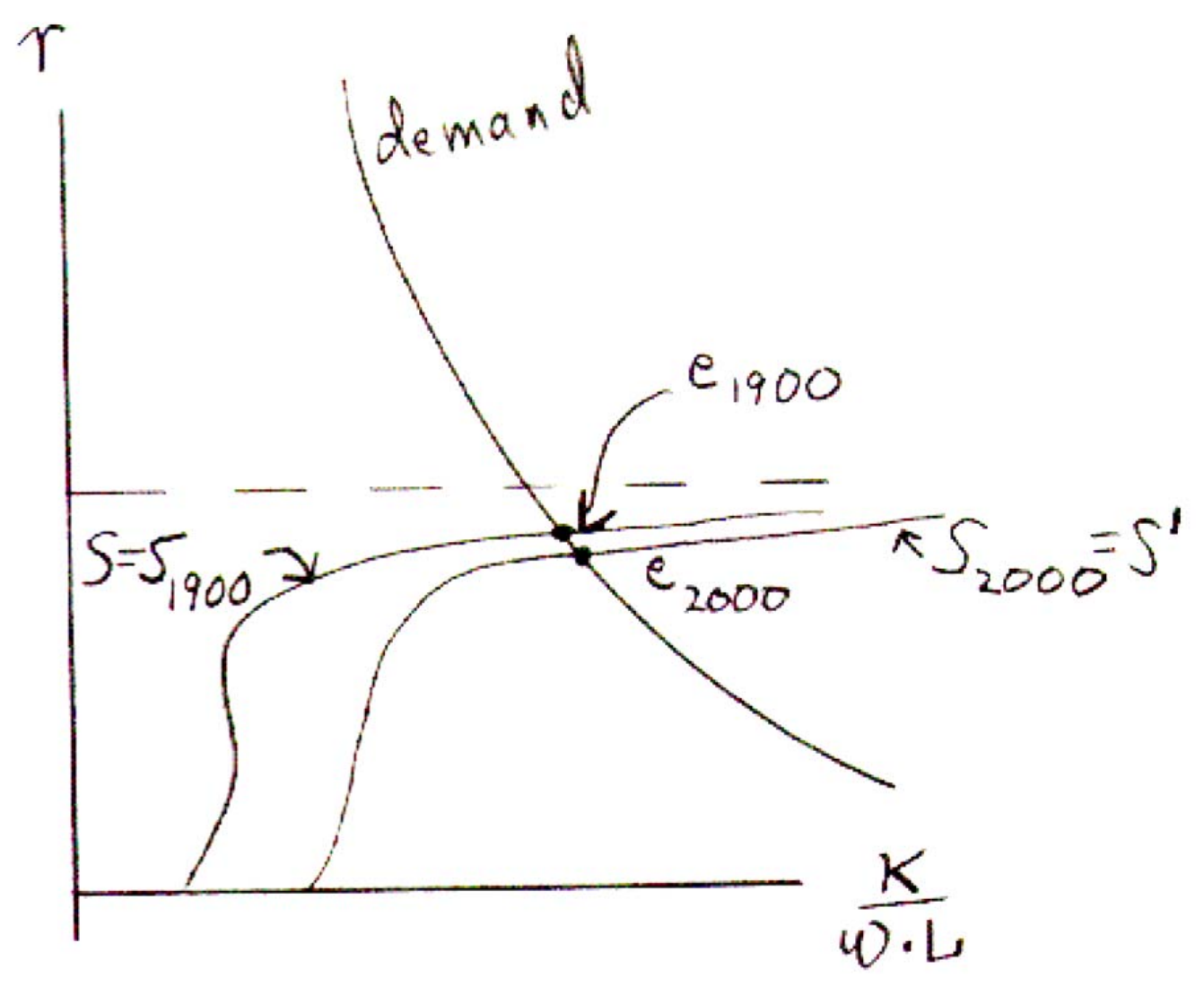

Figure 4. An interpretation of changes over time

34 